\title{
Clinical characteristics and long-term outcomes following surgery combined with adjuvant radiotherapy for patients with frontal sinus malignancies
}

\section{Zekun Wang}

National Cancer Center/Cancer Hospital, Chinese Academy of Medical Sciences and Peking Union Medical College

Jianghu Zhang

National Cancer Center/Cancer Hospital, Chinese Academy of Medical Sciences and Peking Union Medical College

Runye Wu

National Cancer Center/Cancer Hospital, Chinese Academy of Medical Sciences and Peking Union Medical College

Ye Zhang

National Cancer Center/Cancer Hospital, Chinese Academy of Medical Sciences and Peking Union Medical College

Junlin Yi

National Cancer Center/Cancer Hospital, Chinese Academy of Medical Sciences and Peking Union Medical College

Li Gao

National Cancer Center/Cancer Hospital, Chinese Academy of Medical Sciences and Peking Union Medical College

Guozhen Xu

National Cancer Center/Cancer Hospital, Chinese Academy of Medical Sciences and Peking Union Medical College

Jingwei Luo ( $\square$ jingwei-luo@outlook.com )

National Cancer Center/Cancer Hospital, Chinese Academy of Medical Sciences and Peking Union Medical College

\section{Case Report}

Keywords: Frontal Sinus Malignancy, Comprehensive Treatment, Tumor Invasion Pattern.

Posted Date: May 18th, 2021

DOI: https://doi.org/10.21203/rs.3.rs-500448/v1

License: (1) (1) This work is licensed under a Creative Commons Attribution 4.0 International License. Read Full License 


\section{Abstract}

Objective: This study aimed to determine clinicopathologic characteristics of primary frontal sinus malignancies (FSMs) and provide long-term survival results.

Materials and methods: A retrospective study of six cases of primary FSMs at our center from 2006 to 2016 was performed. The demographics characteristics, tumor characteristics, treatment modalities and survival outcomes were recorded.

Results: In this series, the median age was 48 years (30-53 years) and all patients were male. There were five cases with squamous cell carcinoma, and one with osteosarcoma. All cases presented with locally advanced disease without regional lymphatic metastasis, including 5 cases of stage $\Downarrow$ and one of stage $\Downarrow$. The two most common pathways of tumor invasion were as follows: local tumor broke posteriorly through bone wall and invaded dura mater, followed by frontal lobe; local tumor infiltrated downward through the floor of frontal sinus into ethmoid sinus, thereafter invaded laterally orbit and orbital contents. All patients received surgery followed by postoperative radiotherapy at the total doses of 50Gy to 75.95Gy. Among them, only one patient underwent $\mathrm{R} 0$ resection, the rest of patients underwent R1/R2 resection. With a median survival time of 56 months (32 to 76 months), two patients receiving R1/R2 resection developed treatment failure and died within 5 years, including one case with local recurrence, and one with local recurrence thereafter distant metastasis.

Conclusion: The majority of FSMs presented with peripherally invasive progression lesions, which led to a high ratio of R1/R2 resection. Surgery combined with postoperative radiotherapy might result in satisfactory efficacy.

\section{Introduction}

Primary frontal sinus malignancies (FSMs) accounted for approximately $1 \%$ of all sinonasal tumors with an incidence of 0.011 per 100,000 population $[1,2]$. There are diverse histological types for FSMs, with squamous cell carcinoma (SCC) as the main pathological type which represented $40 \%-48 \%$ of cases, followed by Non-Hodgkin's lymphoma (17\%-21\%), non-specific epithelial neoplasm (10\%-14\%), adenocarcinoma (10\%-12\%) and neuroepithelial neoplasm (4\%-6\%) [1, 2]. The frontal sinuses are paired asymmetric air-filled cavities separated by interfrontal septum, between the inner and outer bone plates in the forehead [3]. As a result of the complex anatomical structure of frontal sinus, most patients at diagnosis present with extensive invasion of adjacent structures including ethmoid sinus, nasal cavity, orbit, dura mater and even frontal lobe. However, the specific pattern and frequency of tumor invasion has not been sufficiently explored in FSMs. On the other hand, the extensive invasion of lesions makes it difficult to achieve complete resection with negative margins for FSMs, which often leads to high local failure rates of $31 \%-60 \%$ [4-15]. Given disease rarity, histological diversity, late presentation, invasion of neighboring structures, seldom obtained negative margins, primary frontal sinus malignancies presented enormous challenges to physicians.

As an extremely rare entity, many case reports with heterogeneity described this disease, there was a lack of large case series to date. To our knowledge, there were only two slightly larger single-center case series to be reported before 2000, one including six cases of SCC and the other including five cases of epithelial carcinoma $[4,16]$. Owing to the earlier era, the radiation technique applied Cobalt- 60 and electron beam at that time, and surgical technique was also behind the present, therefore it could not represent the current level of treatment. Since 2000, there was only one population-based analysis from SEER database including 171 FSMs [1], while other studies integrated FSMs into sinonasal tumors for analysis. Unfortunately, population-based study was difficult to ensure correct diagnosis and lack of information on the extent of invasion. In addition, a review of the Chinese-/Englishlanguage literature excluding lymphoma in the same period (Table 1) only identified thirteen cases of primary FSMs in ten case reports and one case series. Under the premise, although our retrospective analysis merely included six primary FSMs, it was still one of the largest single-center case series at present. Our study aimed to determine clinicopathologic characteristics of primary FSMs and provide long-term survival results. 
Table 1

The Chinese-/English-language case reports/case series retrieved on Pubmed in the same period (from 2006 to 2016 )

\begin{tabular}{|c|c|c|c|c|c|c|}
\hline $\begin{array}{l}\text { Authors } \\
\text { (Year) }\end{array}$ & $\begin{array}{l}\text { Age } \\
\text { /Gender }\end{array}$ & Histology & Stage & Treatment Modalities & $\begin{array}{l}\text { Treatment } \\
\text { Failure }\end{array}$ & $\begin{array}{l}\text { Follow-up/ } \\
\text { Status }\end{array}$ \\
\hline $\begin{array}{l}\text { Yoshida. N, et al } \\
(2006)[5]\end{array}$ & 74/Male & SCC & प & $\begin{array}{l}\text { Frontal craniotomy } \\
\rightarrow \mathrm{RT} \text { (50Gy) }\end{array}$ & $\begin{array}{l}\operatorname{LR}(3 \\
\text { months) }\end{array}$ & $\begin{array}{l}\text { 20m/Died of } \\
\text { disease }\end{array}$ \\
\hline $\begin{array}{l}\text { X. Zhang, et al } \\
(2006)[6]\end{array}$ & 55/Female & Osteosarcoma & ] & $\begin{array}{l}\text { Extended lateral rhinotomy } \\
\rightarrow \mathrm{CT}+\mathrm{RT}\end{array}$ & No & $\begin{array}{l}25 \mathrm{~m} / \text { Alive } \\
\text { with no } \\
\text { disease }\end{array}$ \\
\hline Gerlinger. I, et al & 60/Male & Undifferentiated & प & Frontal craniotomy & No & 12m/Alive \\
\hline (2008) [7] & & carcinoma & & $\rightarrow \mathrm{RT}$ & & $\begin{array}{l}\text { with no } \\
\text { disease }\end{array}$ \\
\hline $\begin{array}{l}\text { Tsutomu. Ichinose, } \\
\text { et al }\end{array}$ & 66/Male & SCC & प & Frontal craniotomy & No & $24 \mathrm{~m} /$ Alive \\
\hline (2009) [8] & & & & & & $\begin{array}{l}\text { with no } \\
\text { disease }\end{array}$ \\
\hline $\begin{array}{l}\text { Michael W. Chu, et } \\
\text { al }\end{array}$ & 61/Male & Carcinoid tumor & ] & Endoscopic resection & No & 14m/Alive \\
\hline (2010) [9] & & & & & & $\begin{array}{l}\text { with no } \\
\text { disease }\end{array}$ \\
\hline J. Madana, et al & 48/Female & SCC & ] & Frontal craniotomy & No & 12m/Alive \\
\hline (2011) [10] & & & & $\rightarrow$ RT (64Gy) & & $\begin{array}{l}\text { with no } \\
\text { disease }\end{array}$ \\
\hline $\begin{array}{l}\text { Raman Wadhera, } \\
\text { et al }\end{array}$ & 53/Male & Adenocarcinoma & ] & $\mathrm{CT} \rightarrow \mathrm{RT}$ & NO & $12 \mathrm{~m} /$ lost to \\
\hline (2011) [11] & & & & (Refusal of surgery) & & follow-up \\
\hline R-g. Wang, et al & 47/Female & SCC & ] & Endoscopic + craniotomy & $\begin{array}{l}\text { IM (6 } \\
\text { months) }\end{array}$ & $16 \mathrm{~m} /$ Died of \\
\hline \multirow[t]{5}{*}{ (2011) [15] } & & & & $\rightarrow \mathrm{RT}(60 \mathrm{~Gy})$ & $\rightarrow \mathrm{LR}+\mathrm{DM}$ & disease \\
\hline & 59/Male & SCC & ] & Endoscopic + craniotomy & $\begin{array}{l}\text { LR }(40 \\
\text { days) }\end{array}$ & $10 \mathrm{~m} /$ Died of \\
\hline & & & & $\rightarrow$ RT (60Gy) & $\begin{array}{l}\rightarrow \mathrm{BM}(4 \\
\text { months) }\end{array}$ & disease \\
\hline & 60/Female & SCC & प & Endoscopic + craniotomy & $\begin{array}{l}\text { LR (14 } \\
\text { months) }\end{array}$ & $21 \mathrm{~m} /$ Alive \\
\hline & & & & $\rightarrow \mathrm{RT}$ & & with disease \\
\hline $\begin{array}{l}\text { Seiji Hosokawa, et } \\
\text { al }\end{array}$ & 71/Male & SpCC & ] & Frontal skull base & No & 40m/Alive \\
\hline (2012) [12] & & & & craniotomy & & $\begin{array}{l}\text { with no } \\
\text { disease }\end{array}$ \\
\hline $\begin{array}{l}\text { Senja Tomovic, et } \\
\mathrm{al}^{\dagger}\end{array}$ & 21/Female & Angiosarcoma & ] & CT (6 months) & Recurrence & 12m/Alive \\
\hline (2014) [13] & & & & (gemcitabine/ docetaxel) & & \\
\hline H.Z. Zhang, et al & 66/Male & SCC & ] & Frontal craniotomy & No & $6 \mathrm{~m} /$ Alive \\
\hline
\end{tabular}




\begin{tabular}{|c|c|c|c|c|c|c|}
\hline $\begin{array}{l}\text { Authors } \\
\text { (Year) }\end{array}$ & $\begin{array}{l}\text { Age } \\
\text { /Gender }\end{array}$ & Histology & Stage & Treatment Modalities & $\begin{array}{l}\text { Treatment } \\
\text { Failure }\end{array}$ & $\begin{array}{l}\text { Follow-up/ } \\
\text { Status }\end{array}$ \\
\hline (2014) [14] & & & & $\rightarrow$ RT (50Gy/15f) & & $\begin{array}{l}\text { with no } \\
\text { disease }\end{array}$ \\
\hline
\end{tabular}

\section{Materials And Methods}

\section{Patient selection and staging evaluation}

Between March 2006 and October 2016, seven patients diagnosed as primary FSM were treated at Cancer Hospital of Chinese Academy of Medical Sciences (CAMS) and Peking Union Medical College (PUMC). One patient with recurrence disease who needed salvage surgery was excluded. A total of 6 patients were included in this retrospective analysis. At present, FSM had not been included in the American Joint Committee on Cancer (AJCC) staging system. The most common staging system currently applied to FSM was developed at the University of Florida (Table 2) [17]. All cases were restaged according to The University of Florida Staging System. The medical records of all patients were reviewed, including medical history, head and neck specialist examination, endoscope, computed tomography (CT) scan and/or magnetic resonance imaging (MRI) of paranasal sinus, neck and chest CT scan, and abdomen ultrasound. The demographic features, tumor characteristics, clinical manifestation, surgical records, radiation data, and detailed follow-up information were available for each patient.

Table 2

The University of Florida Staging System

\begin{tabular}{|c|c|}
\hline Category & Criteria \\
\hline 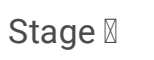 & tumors limited to the site of origin \\
\hline \multirow[t]{2}{*}{ Stage $\otimes$} & extension to adjacent sites (orbit, paranasal sinuses, skin, nasopharynx, \\
\hline & pterygomaxillary fossa) \\
\hline Stage $\rrbracket$ & base of skull or pterygoid plate destruction and/or intracranial extension \\
\hline
\end{tabular}

\section{Treatment modalities}

In this series, all patients received combined treatment consisting of surgery and postoperative radiotherapy (PORT). The patient 2 , patient 4 and patient 6 were treated with tumor enucleation at other institutions before secondary extended operation due to misdiagnosis of benign diseases. During secondary extended operation, all patients followed the principle of en bloc resection. The anterior skull base resection and extended skull base resection were performed in patient 2 and patient 4 respectively, who simultaneously received orbital contents exenteration, while the patient 6 received extended frontal sinusectomy. Of the three previously untreated patients, two patients underwent anterior craniofacial resection via coronal scalp incision in line with the principle of en bloc resection, one was treated with lateral rhinotomy combined with endoscopic technique. The free flap reconstruction was performed in three cases to repair large defects of frontal skin. None of the patients underwent neck dissection.

The median interval time between surgery and radiotherapy was 1.9 months (range: 1.0 to 3.6 months). The three patients were treated with intensity modulated radiation therapy (IMRT), two patients were treated with helical tomotherapy (TOMO), and one received volumetric modulated arc therapy (VMAT). The median radiation dose of this series was 68Gy (50Gy-75.95Gy) at a daily dose range of 2.0Gy-2.17Gy to the tumor bed boost, of which the doses of R1 resection subset ranged from 65.22Gy to 75.95Gy, one patient with R2 resection was delivered a total dose of 69.96Gy, and one with R0 resection was delivered a total dose of 50Gy. The two patients were delivered prophylaxis irradiation of nodal regions at doses of 60.06Gy and 60.20Gy, respectively. Wherein the radiation region of patient 3 covered bilateral level $\nabla, \nabla, \varangle, \nabla$ and retropharyngeal region. The patient 5 were delivered elective 
nodal irradiation including unilateral level $\mathrm{lb}, \otimes$ and retropharyngeal regions. Only the patient with $\mathrm{R} 2$ resection received two cycles of concurrent chemotherapy with cisplatin in $100 \mathrm{mg} / \mathrm{m}^{2}$ intravenously.

\section{Statistical analysis}

The survival time was measured from the date of radical operation to death of any cause. The failure-free survival time was to first treatment failure or last follow-up visit. The descriptive statistics was adopted to summarize clinicopathologic characteristics, treatment outcomes, failure patterns. According to the sequence of symptoms and signs, preoperative MRI and/or CT, intraoperative findings, and postoperative pathology, the presence or absence of tumor invasion and pathways of tumor invasion were identified. The degree of surgical resection depended on intraoperative findings, postoperative pathology, and pre-radiation MRI and/or CT, which was divided into three categories: 1) R0 resection: negative resection margins and no residual tumor; 2) R1 resection: microscopic positive resection margins, but no macroscopic residual tumor; 3) R2 resection: macroscopic positive resection margins or residual tumor.

\section{Results}

\section{Clinicopathologic characteristics}

The characteristics of the cases were summarized in Table 3. The median age of this series was 48 (30-53) years and all patients were male. There were five cases with squamous cell carcinoma (SCC), and one with osteosarcoma. The most common

presenting symptoms and signs were proptosis (66.7\%) and visual impairment (50.0\%), while nasal obstruction was relatively rare, accounting for only $16.7 \%$. Most patients presented with locally advanced disease, of which five cases were classified as stage $\nabla$

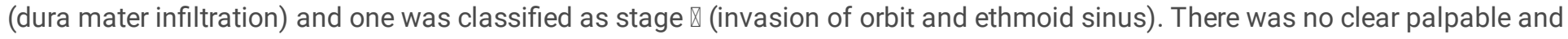
radiographic evidence of lymph node metastasis in all patients at initial diagnosis. 
Table 3

The clinical characteristics, treatment factors and outcomes

\begin{tabular}{|c|c|c|c|c|c|c|c|c|c|}
\hline No. & Age/Gender & Histology & Stage & Symptoms & $\begin{array}{l}\text { Surgical } \\
\text { Approach }\end{array}$ & $\begin{array}{l}\text { Degree of } \\
\text { Resection }\end{array}$ & $\begin{array}{l}\text { Radiation } \\
\text { Technique }\end{array}$ & $\begin{array}{l}\text { Radiation } \\
\text { Dose }\end{array}$ & $\begin{array}{l}\text { Follow-up } \\
\text { /Status }\end{array}$ \\
\hline 1 & 48/Male & SCC & ] & $\begin{array}{l}\text { Visual } \\
\text { impairment, } \\
\text { proptosis }\end{array}$ & $\begin{array}{l}\text { lateral } \\
\text { rhinotomy } \\
\text { +Endoscopic }\end{array}$ & $\mathrm{R} 1$ & IMRT & $65.22 \mathrm{~Gy}$ & $\begin{array}{l}47 \mathrm{~m} / \text { Died } \\
\text { of } \\
\text { disease }\end{array}$ \\
\hline 2 & 48/Male & SCC & प & $\begin{array}{l}\text { Forehead } \\
\text { pain, } \\
\text { numbness }\end{array}$ & $\begin{array}{l}\text { Anterior } \\
\text { skull } \\
\text { base } \\
\text { resection }\end{array}$ & $\mathrm{R} 1$ & IMRT & $75.95 \mathrm{~Gy}$ & $\begin{array}{l}32 \mathrm{~m} / \text { Died } \\
\text { of } \\
\text { disease }\end{array}$ \\
\hline 3 & 49/Male & SCC & $\square$ & $\begin{array}{l}\text { Nasal } \\
\text { obstruction, } \\
\text { visual } \\
\text { impairment, } \\
\text { proptosis, } \\
\text { diplopia }\end{array}$ & $\begin{array}{l}\text { Craniofacial } \\
\text { resection }\end{array}$ & $\mathrm{R} 2$ & TOMO & 69.96Gy & $\begin{array}{l}65 \mathrm{~m} / \text { Alive } \\
\text { with } \\
\text { no } \\
\text { disease }\end{array}$ \\
\hline \multirow[t]{2}{*}{4} & 53/Male & SCC & $\square$ & $\begin{array}{l}\text { Forehead } \\
\text { swelling }\end{array}$ & $\begin{array}{l}\text { Extended } \\
\text { skull }\end{array}$ & Ro & IMRT & $50.0 \mathrm{~Gy}$ & $\begin{array}{l}76 \mathrm{~m} / \text { Alive } \\
\text { with }\end{array}$ \\
\hline & & & & & $\begin{array}{l}\text { base } \\
\text { resection }\end{array}$ & & & & $\begin{array}{l}\text { no } \\
\text { disease }\end{array}$ \\
\hline \multirow[t]{2}{*}{5} & 45/Male & SCC & $\square$ & $\begin{array}{l}\text { Visual } \\
\text { impairment, }\end{array}$ & Craniofacial & $\mathrm{R} 1$ & VMAT & 70.0Gy & $\begin{array}{l}67 \mathrm{~m} / \text { Alive } \\
\text { with }\end{array}$ \\
\hline & & & & $\begin{array}{l}\text { proptosis, } \\
\text { headache }\end{array}$ & resection & & & & $\begin{array}{l}\text { no } \\
\text { disease }\end{array}$ \\
\hline \multirow[t]{2}{*}{6} & 30/Male & Osteo- & प & $\begin{array}{l}\text { Forehead } \\
\text { swelling, }\end{array}$ & Extended & $\mathrm{R} 1$ & TOMO & 66.0Gy & $\begin{array}{l}37 \mathrm{~m} / \text { Alive } \\
\text { with }\end{array}$ \\
\hline & & sarcoma & & $\begin{array}{l}\text { proptosis, } \\
\text { numbness }\end{array}$ & sinusectomy & & & & $\begin{array}{l}\text { no } \\
\text { disease }\end{array}$ \\
\hline $\begin{array}{l}\mathrm{Abb} \\
\mathrm{ma} \\
\mathrm{Rac}\end{array}$ & $\begin{array}{l}\text { ation: Ro: } n \\
\text { copic residu } \\
\text { on Therapy; }\end{array}$ & ive resect & $\begin{array}{l}\text { marg } \\
\text { acrosc }\end{array}$ & and no resi & $\begin{array}{l}\text { tumor; R1: } \\
\text { ion margin }\end{array}$ & $\begin{array}{l}\text { oscopic p } \\
\text { esidual th }\end{array}$ & $\begin{array}{l}\text { tive resec } \\
\text { r; IMRT: Ir }\end{array}$ & $\begin{array}{l}\text { margins, } \\
\text { sity Modi }\end{array}$ & $\begin{array}{l}\text { no } \\
\text { ed }\end{array}$ \\
\hline
\end{tabular}

\section{The pathways of tumor invasion}

Based on the patterns of tumor invasion, four infiltration pathways were identified (Fig. 1). The two most common routes were as follows: 1) local tumor broke posteriorly through bone wall and invaded dura mater, followed by frontal lobe; 2) local tumor infiltrated downward through the floor of frontal sinus into ethmoid sinus, thereafter invaded laterally orbit and orbital contents. Among the 5 patients with ethmoid sinus involvement, all cases had invasion of the orbital bone wall, finally only one case infringed on the orbital contents. In addition, there was also one case anteriorly and inferiorly spreading to nasal cavity at the same time. The least common pathway was local lesions penetrating laterally and downward into the orbit, followed by intraorbital infiltration.

\section{Treatment outcomes}

In terms of resection status, only one case received R0 resection, four cases underwent R1 resection, and the remaining one underwent R2 resection who had complete tumor regression after PORT (Table 3). After the long-term follow-up, the overall median survival time was 56 months (32 to 76 months). During the follow-up, patient 1 and patient 2 receiving R1 resection developed treatment failure and died within 5 years. Of the two patients, the failure-free survival time was 21 months and 3 months, 
respectively. By the end of the last follow-up, among the other 4 patients who did not experience treatment failure, three patients survived more than 5 years and one survived over 3 years.

\section{Failure patterns}

As stated previously, two cases (33.3\%) developed treatment failure. Of the two patients, one case developed the skull base recurrence and intracranial progression in 21 months as well as 34 months after surgery, respectively. Another case developed local recurrences of the orbit for three times in 3 months, 14 months, and 18 months after surgery. Additionally, the patient also developed lung metastasis in 9 months after surgery. Although both patients received salvage therapy including surgery alone or surgery combined with radiation and chemotherapy, they still died of the progression of local lesions. By the end of the last followup, there was no regional lymph node failure in this series.

\section{Treatment complications and toxicities}

After primary surgery, two patients experienced surgical complications including one case with postoperative infection of residual cavity and the other one with intermediate hemoglobin reduction as well as epiphora. In addition, postoperative radiotherapy was postponed in the two patients due to infection and hemoglobin reduction. The interval time was 2.8 months in one patient and 3.6 months in the other. In terms of radiation toxicities, among the four long-term surviving patients, only patient 3 developed asymptomatic radiation necrosis of frontal lobe, intermediate vision loss and mild hearing loss during the follow-up.

\section{Discussion}

This is a large single-center retrospective cohort study with consistent treatment modality including surgery and radiotherapy, which has achieved good survival results. The majority of frontal sinus malignancies present with peripherally invasive progression lesions without regional lymph node metastasis. And most of them fail to achieve complete resection with negative margins, suggesting the importance of postoperative radiotherapy and the potential role of neoadjuvant therapy. Local recurrence is still the predominant failure pattern, and no regional lymph node failure has been found. In addition, this is also the first study to identify the tumor invasion pathways of primary frontal sinus malignancies.

Regarding the characteristics of entire cohort, our series included only six males, aging from 30 to 53 years, which was similar to the male predominance of sinonasal tumors, but different from the peak incidence in the 5th and 6 th decades of life $[2,18]$. The most possible reason was the selection bias because of small sample sizes. Basically consistent with the incidence of $90 \%$ reported in the previous literatures [19], SCC occupied an absolute superiority (83.3\%) in our series, which was higher than the proportion of SCC ranging $42-54 \%$ in sinonasal tumors $[2,20]$. However, the contradictory results were that two large populationbased studies showed that SCC accounted for $40 \%-48 \%$ of frontal sinus tumors [1, 2]. On one hand, it might be due to the bias caused by small sample size in our study. On the other hand, it should not be ignored that the population-based study was difficult to ensure the correct diagnosis and lymphoma was usually included for analysis. Considering tumor characteristics, both six cases from our cohort and 13 cases summarized in Table 1 were stage II or III at diagnosis. Consistent with this, the populationbased analysis including 171 FSMs showed localized diseases (no tumor invasion) represented only $11 \%$ [1]. In comparison to FSMs, many studies reported that locally advanced lesions (T3 or T4) accounted for $60 \%-75 \%$ of overall sinonasal tumors [2, 20 ,

21], demonstrating FSMs were more prone to present with extensive invasion of adjacent sites than other paranasal sinus tumors. Although many studies reported that overall lymphatic metastasis of sinonasal tumors at diagnosis usually occured in 10-20\% of patients [20,22], which could be as high as $30 \%$ in squamous cell or poorly differentiated carcinoma of maxillary sinus [23], the incidence of lymphatic metastasis for FSMs was seldom reported. According to our experience, regional lymphatic metastasis rarely occurred in FSMs with the exception of lymphoma. Neither our series nor the 13 cases listed in Table 1 found regional lymphatic metastasis at initial diagnosis, which was also in support of this theme.

Our study also described four specific pathways of tumor invasion, which deepened the understanding of the clinicopathological characteristics of FSMs. Anatomically, the floor of the frontal sinus was the thinnest and easily invaded by tumor, which explained why frontal sinus lesions were more likely to invade downward the ethmoid sinus. And commonly lateral invasion from the ethmoid sinus to the orbit was owing to the thin lamina papyracea. On the other hand, the inner plate of frontal bone was thinner than the outer plate, which could lead to another common route with posteriorly invading the dura mater. Given the extensive infiltration of FSMs, we hypothesized that clinical target volume (CTV) should routinely include these high-risk areas. In addition, 
the unique tumor invasion pattern of primary FSMs made its symptoms and signs different from other sinonasal tumors. To our knowledge, the most common described symptoms at initial diagnosis included nasal obstruction, nasal discharge, epistaxis, mass in the nose, and facial pain [23]. However, our data demonstrated that nasal obstruction occurred in only one patient, and ocular symptoms including proptosis as well as visual impairment were the most common, consistent with the high orbital invasion rate of our cohort.

The multimodality treatment consisting of surgery and radiotherapy had been shown to improve clinical outcomes of advancedstage sinonasal tumors, compared with single-modality therapy [20,24, 25]. Our study also adopted the unified treatment modality of surgery and adjuvant radiotherapy. Transfacial or craniofacial approach could provide a wide range of potential en bloc resection for anterior skull base tumors involving the dura mater [26]. Whereas, craniofacial approach provided greater exposure to the ventral skull base, especially when the frontal lobe was invaded [26]. In our study, three cases were treated with transfacial approach, one received endoscopic combined with transfacial approach, and other cases with invasion of frontal lobe underwent craniofacial resection. Even if the principle of en bloc resection was followed, the R0 resection rate was still extremely low, only $16.7 \%$. In this condition, the treatment strategy of surgery and adjuvant radiotherapy obtained good clinical efficacy with the median survival time of 56 months, illustrating the importance of adjuvant radiotherapy and the value of comprehensive treatment. In an early single-center case study, Frew retrospectively analyzed six cases of frontal sinus SCC receiving radiotherapy alone, with a median survival time of only 13 months [16].

The existing literatures described that the overall treatment failure rates of sinonasal tumors ranged from $41-67 \%[21,27,28]$, and local recurrence was the predominant failure pattern. Likewise, our study yielded the similar results with a slightly lower treatment failure rate. Additionally, in the condition of only 2 cases receiving cervical prophylaxis irradiation, there was no regional lymph node failure in our cohort during the follow-up. Brownson et al also reported the regional lymphatic metastases rate of FSMs was less than $10 \%$ [4]. Due to extremely rare regional lymph node metastases and failure, cervical prophylaxis irradiation might be not necessary for primary FSMs, which could help reduce treatment toxicities. In terms of surgical complications, although PORT was postponed in the two patients due to complications, it did not affect the clinical efficacy. As for radiation toxicities, although patient 3 experienced frontal necrosis and hearing loss, the patient received R2 resection with avoiding removal of orbital contents, thereby preserved part of the vision and developed no treatment failure, indicating that the organ-sparing surgery plus adjuvant radiotherapy might result in satisfactory outcomes. Overall, the complications and toxicities were tolerable for our cohort.

Despite our study provided long-term survival results of surgery combined with PORT for primary FSMs, there were still many limitations due to small sample size. Firstly, the case selection bias from retrospective analysis was particularly magnified in small sample studies, such as the distribution of pathologic type, age, and gender discussed previously. Thereafter, although all cases in this study adopted combined treatment modality of surgery and adjuvant radiotherapy, the surgical approach were not uniform, which affected inductive analysis of case series to a certain extent. Lastly, our experience was based on an inductive analysis of limited cases, therefore it was far from extrapolating conclusions in optimal treatment of primary frontal sinus malignancies.

\section{Conclusion}

Primary frontal sinus malignancies are more common in male, squamous cell carcinoma is the main histologic type, and the majority present with peripherally invasive progression lesions. The two most common pathways of tumor invasion are as follows: local tumor breaks posteriorly through bone wall and invades dura mater, followed by frontal lobe; local tumor infiltrates downward through the floor of frontal sinus into ethmoid sinus, thereafter invades laterally orbit and orbital contents. Compared with other paranasal sinus tumors, surgery usually leads to a high ratio of R1/2 resection for frontal sinus malignancies. But surgery combined with radiotherapy achieves long-term survival results and local recurrence is still the predominant failure pattern. Regional lymph node metastasis and failure are extremely rare, illustrating cervical prophylaxis irradiation might be not necessary. The treatment strategies should focus on improving complete resection rate and local control in the future.

\section{Abbreviations}


SCC: Squamous cell carcinoma; SpCC:Spindle cell carcinoma; CT:Chemotherapy; RT:Radiotherapy; NA:Not available; CR:Complete response; SD: Stable disease; LR:Local recurrence; IM:Implantation metastasis; DM:Distant metastasis; BM:Bone metastasis.

\section{Declarations}

\section{Conflicts of interests:}

The authors have no conflicts of interest to declare that are relevant to the content of this article.

\section{Ethics approval:}

Ethical approval was waived by the local Ethics Committee of National Cancer Center/ Cancer Hospital, Chinese Academy of Medical Sciences and Peking Union Medical College in view of the retrospective nature of the study and all the procedures being performed were part of the routine care.

\section{Consent to participate:}

Verbal informed consent was obtained prior to the interview.

\section{Consent to publish:}

The participant has consented to the submission of the case report to the journal.

\section{Data availability:}

All data generated or analyzed during this study are included in this published article

\section{Authors' contributions:}

Study concepts and design: Zekun Wang, Jingwei Luo

Data acquisition: Jianghu Zhang, Runye Wu, Ye Zhang, Junlin Yi, Li Gao, Guozhen Xu, Jingwei Luo

Data analysis and interpretation: Zekun Wang

Statistical analysis: Zekun Wang

Manuscript editing: Zekun Wang, Jingwei Luo

Manuscript review and approvement: Zekun Wang,Jianghu Zhang, Runye Wu, Ye Zhang, Junlin Yi, Li Gao, Guozhen Xu, Jingwei Luo.

\section{References}

1. Bhojwani A, Unsal A, Dubal PM et al. Frontal Sinus Malignancies: A Population-Based Analysis of Incidence and Survival. Otolaryngol Head Neck Surg 2016; 154: 735-741. https://doi.org/10.1177/0194599815621878

2. Dutta R, Dubal PM, Svider PF et al. Sinonasal malignancies: A population-based analysis of site-specific incidence and survival. Laryngoscope 2015; 125: 2491-2497. https://doi.org/10.1002/lary.25465

3. Vázquez A, Baredes S, Setzen M, Eloy JA. Overview of Frontal Sinus Pathology and Management. Otolaryngologic Clinics of North America 2016; 49: 899-910. https://doi.org/10.1016/j.otc.2016.03.014

4. Brownson RJ, Ogura JH. Primary carcinoma of the frontal sinus. The Laryngoscope 1971; 81: 71-89. https://doi.org/10.1288/00005537-197101000-00007

5. Yoshida N, Kanekura T, Hashiguchi T et al. Primary squamous cell carcinoma of the frontal sinus. J Dermatol 2006; 33: 855857. https://doi.org/10.1111/j.1346-8138.2006.00195.x 
6. Zhang $\mathrm{X}$, Yang $\mathrm{C}$, Kong $\mathrm{W}$ et al. Osteogenic sarcoma in frontal sinus: one case with literature review. Lin chuang er bi yan hou ke za zhi = Journal of clinical otorhinolaryngology 2006; 20: 1130-1131.

7. Gerlinger I, Gobel G, Toth E et al. Primary carcinoma of the frontal sinus: a case report and a review of literature. Eur Arch Otorhinolaryngol 2008; 265: 593-597. https://doi.org/10.1007/s00405-007-0491-x

8. Ichinose T, Goto T, Motomura H et al. Primary Squamous Cell Carcinoma of the Frontal Sinus Treated With En Bloc Resection\&mdash;Case Report\&mdash. Neurologia medico-chirurgica 2009; 49: 481-483. https://doi.org/10.2176/nmc.49.481

9. Chu MW, Karakla DW, Silverberg M, Han JK. Primary Carcinoid Tumor of the Frontal Sinus: A Case Report. Ear, Nose \& Throat Journal 2010; 89: E13-E16. https://doi.org/10.1177/014556131008901003

10. Madana J, Yolmo D, Gopalakrishnan S, Saxena SK. Primary frontal sinus carcinoma with extradural anterior cranial fossa involvement. Ear Nose Throat J 2011; 90: E4-7. https://doi.org/10.1177/014556131109001016

11. Wadhera R, Gulati SP, Garg A et al. Primary adenocarcinoma of the frontal sinus. Ear, nose, \& throat journal 2011; 90 : E23-E25. https://doi.org/10.1177/014556131109001022

12. Hosokawa S, Okamura J, Sakai N, Mineta H. Primary spindle cell carcinoma of the frontal sinus. J Oral Maxillofac Surg 2012; 70: e674-678. https://doi.org/10.1016/j.joms.2012.07.025

13. Tomovic S, Kalyoussef E, Mirani NM et al. Angiosarcoma arising from the frontal sinus. Am J Otolaryngol 2014; $35: 806-809$. https://doi.org/10.1016/j.amjoto.2014.08.003

14. Zhang HZ, Li YP, She $L$ et al. Primary carcinoma of the frontal sinus with extensive intracranial invasion: A case report and review of the literature. Oncol Lett 2014; 7: 1915-1918. https://doi.org/10.3892/ol.2014.2032

15. Wang R-g, Wang G, Chen L. Three cases of primary squamous cell carcinoma in the frontal sinus. Zhonghua er bi yan hou tou jing wai ke za zhi = Chinese journal of otorhinolaryngology head and neck surgery 2011; 46: 664-668.

16. Frew I. Frontal sinus carcinoma. The Journal of laryngology and otology 1969; 83: 393-396. https://doi.org/10.1017/s002221510007047x

17. Tirelli G, Capriotti V, Sartori G et al. Primary Adenoid Cystic Carcinoma of the Frontal Sinus: Case Description of a Previously Unreported Entity and Literature Review. Ear Nose Throat J 2019; 98: E8-E12. https://doi.org/10.1177/0145561319837881

18. Danesh-Sani SA, Sarafraz A, Chamani M, Derakhshandeh H. Paranasal sinuses malignancies: A 12-year review of clinical characteristics. Medicina Oral Patología Oral y Cirugia Bucal 2016; 0-0. https://doi.org/10.4317/medoral.21170

19. G.Gourin C, J.Terris D. Frontal Sinus Malignancies. In E.Kountakis S, A.Senior B, Draf W (eds): The Frontal Sinus, 1st Edition. Germany: Springer-Verlag 2005; 167.

20. Robin TP, Jones BL, Gordon OM et al. A comprehensive comparative analysis of treatment modalities for sinonasal malignancies. Cancer 2017; 123: 3040-3049. https://doi.org/10.1002/cncr.30686

21. Thorup C, Sebbesen L, Dano H et al. Carcinoma of the nasal cavity and paranasal sinuses in Denmark 1995-2004. Acta Oncol 2010; 49: 389-394. https://doi.org/10.3109/02841860903428176

22. Llorente JL, Lopez F, Suarez C, Hermsen MA. Sinonasal carcinoma: clinical, pathological, genetic and therapeutic advances. Nat Rev Clin Oncol 2014; 11: 460-472. https://doi.org/10.1038/nrclinonc.2014.97

23. Siddiqui F, Smith RV, Yom SS et al. ACR appropriateness criteria((R)) nasal cavity and paranasal sinus cancers. Head Neck 2017; 39: 407-418. https://doi.org/10.1002/hed.24639

24. Guntinas-Lichius $\mathrm{O}$, Kreppel MP, Stuetzer $\mathrm{H}$ et al. Single modality and multimodality treatment of nasal and paranasal sinuses cancer: a single institution experience of 229 patients. Eur J Surg Oncol 2007; 33: 222-228.

https://doi.org/10.1016/j.ejso.2006.10.033

25. Banuchi V, Mallen J, Kraus D. Cancers of the nose, sinus, and skull base. Surg Oncol Clin N Am 2015; 24: 563-577. https://doi.org/10.1016/j.soc.2015.03.009

26. Perkins EL, Brandon BM, Sreenath SB et al. Transfacial and Craniofacial Approaches for Resection of Sinonasal and Ventral Skull Base Malignancies. Otolaryngol Clin North Am 2017; 50: 287-300. https://doi.org/10.1016/j.otc.2016.12.006

27. Guan X, Wang X, Liu Y et al. Lymph node metastasis in sinonasal squamous cell carcinoma treated with IMRT/3D-CRT. Oral Oncol 2013; 49: 60-65. https://doi.org/10.1016/j.oraloncology.2012.07.009

Page $10 / 11$ 
28. Wiegner EA, Daly ME, Murphy JD et al. Intensity-modulated radiotherapy for tumors of the nasal cavity and paranasal sinuses: clinical outcomes and patterns of failure. Int J Radiat Oncol Biol Phys 2012; 83: 243-251.

https://doi.org/10.1016/j.ijrobp.2011.05.044

\section{Figures}

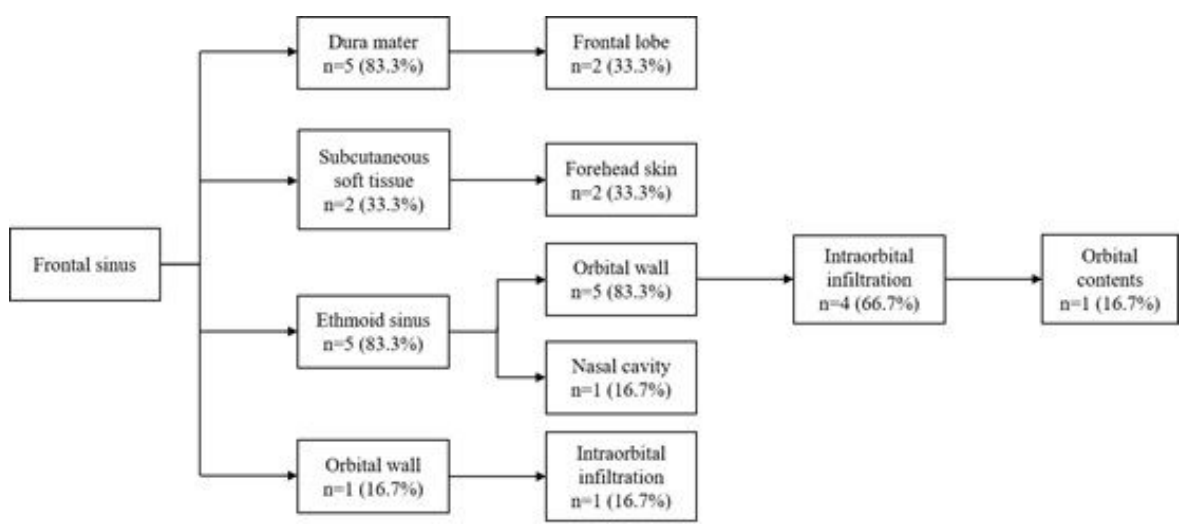

\section{Figure 1}

Pathways of tumor invasion for primary frontal sinus malignancies 